\title{
FOOD SAFETY AS ONE OF THE MAIN SAFETY PREOCCUPATIONS OF A MODERN MAN
}

\author{
Željko Bjelajac ${ }^{1}$, Marijana Dukić - Mijatovićn ${ }^{2}$ Joko Dragojlović ${ }^{3}$
}

\begin{abstract}
Summary
Industrialization, agricultural production and use of hormones, additives, pesticides, and like have influenced the increase in customers' dissatisfaction, leading to loss of their confidence in institutions responsible for food safety control. It resulted in changes and adoption of more stringent legal regulations that followed the concept "from farm to fork" at the level of the European Union and the Republic of Serbia. It puts the emphasis on consumers and their right to have important facts for the proper selection of products (food) at their disposal. Consequently, the international standards which ensure the quality and safety of food are being developed. Therefore, the aim of this paper is to analyze food safety from the aspect of modern man through the methodological and theoretical framework. Analysis method will explain terms related to the food safety, while the normative method will be used to see legislation regulating the studying matter of food safety and consumer protection in the European Union and the Republic of Serbia, and the obtained results will be compared and summarized through comparative method.
\end{abstract}

Keywords: food safety, consumer protection, international standards, EU, harmonization, Republic of Serbia.

JEL: K32, F64, Q19.

\section{Introduction}

Food safety in the narrow sense can be defined as the absence of risk in food, while in the broader sense it can include nutritional characteristics and information about the unknown

1 Željko Bjelajac Ph.D., Full professor, University of Business Academy, Law Faculty of Economics and Justice, Geri Karolja Street no. 1, 21000 Novi Sad, Republic of Serbia, Phone: +381 644628 967, E-mail: zdjbjelajac@gmail.com

2 Marijana Dukić-Mijatović Ph.D., Full professor, University of Business Academy, Law Faculty of Economics and Justice, and University Novi Sad, Faculty of economy in Subotica, Segedinski put no. 9-11 24000 Subotica, Republic of Serbia, Phone: +381 63542 093, E-mail: marijana.dukic.mijatovic@gmail.com

3 Joko Dragojlović Ph.D., Assistant professor, University of Business Academy, Law Faculty of Economics and Justice, Geri Karolja Street no. 1, 21000 Novi Sad, Republic of Serbia, Phone: +381 649429 936, E-mail: jdragojlovic@pravni-fakultet.info

EP 2017 (64) 1 (191-204) 
properties of food such as possible genetically modified food, and the like. According to the Codex Alimentarius, safe food is the food that will not harm consumer when consuming or preparing it in accordance with its intended purpose. The World Health Organization (WHO) puts an emphasis on responsibility in defining food safety. It defines the approach to food safety as a shared responsibility of the food industry, government, consumers, and science. Analogous to the above, it can be concluded that the concept of food safety system is very complex as it is about food which has to be a drug and not a poison to a modern man (Pejanović, 2015).

The importance of food safety and human nutrition have been emphasized through centuries. Thus, the significance of nutrition was suggested by Hippocrates (460-357 BC), considering that the one who does know anything about food cannot understand human diseases. As a confirmation to this, Colin Campbell in his work „The Power of Nutrition“, based on research on the effects of nutrition to human health stated that connectivity is established between various dietary factors and diseases, and in particular stressed the negative impact of protein of animal origin and the positive impact of vegetable protein on human health (Mijatović, Mirčevski, 2012).

The Romans took good care about food safety, and especially prominent personalities or those who feared that they could be poisoned by food. In fact, they had a special slave (lat. praegustator) who had to try the food before serving and to control the entire chain of food preparation, from raw material to serving (Sič, 2013).

Today, quality and safety of food also have an important role in maintaining the health of consumers. A growing concern of state authorities, but also consumers for food safety has contributed to the tightening of legal regulations and the introduction of standards which aim to improve the management of food safety (Baltić et al., 2013).

It is not allowed to place food that is health unsafe for consumers in the European Union; therefore, they pay much attention to this issue in the European Union. (Dukić Mijatović, Gongeta, 2015) Actually, most of the laws in force in the European Union countries were brought by the European Commission, and not the institutions of national legislation. The first group of legal acts is directives which establish goals but allow the national authorities to determine the extent to which these goals are realized, and they cannot be applied if the national legislation does not implement them. The second group of legal acts is regulations which are directly applicable and become applicable in the Member States of the European Union as soon as they come into force without the need to change national legislation. Therefore, within this paper, special attention will be paid to the legislations that regulate the field concerning food safety in the European Union and the Republic of Serbia.

\section{Methodology}

The objective of this work is to analyze food safety through the methodological and theoretical framework and from the aspect of a modern man. Analysis method will explain terms related to food safety. By using this method we should become familiar with basic concepts related to the field of food safety and thus highlight the importance of food safety as one of the 
main preoccupations of a modern man. Normative methods will serve to show us legislations which regulate the examined matter of food safety and consumer protection in the European Union and the Republic of Serbia. By using this method, we will point out the most important legislation related to this area, as well as the most important legal regulations regarding food safety in Serbia and the European Union. Through a comparative method, we will point out the diversity of legitimate regulations applied in Serbia and European Union, and the results will be compared and analyzed, both positive and negative sides of different legal regulations.

\section{Food Safety and Legislation}

According to the World Health Organization, stated by Pejanović (2015), the frequency of food poisoning in industrialized countries in the past ten years has been between 10 and 15 percent per year, while the incidence of milk and dairy products poisoning is estimated at around five percent per year. In 11 European countries, the survey confirmed that out of 100,000 inhabitants 30,000 have problems (suffer) of gastrointestinal infections caused by biological contamination of food. The data obtained in the US show that around 76 million people get poisoned by food every year. Out of this number, an average of 325,000 gets hospitalized, while 5,000 of poisoned people die. These data are alarming for mankind (consumers), which results in the need to increase the consumer protection.

For food protection, and its hygienic safety and quality are responsible manufacturers, government agencies, and consumers. (Dukić Mijatović et al., 2016) In order to provide good quality and safe food at the global level, the World Health Organization and the Food and Agriculture Organization (FAO) of the United Nations created an international system of rules called Codex Alimentarius in 1962 and formed a commission responsible for the program related to standards in the area of food. In each country, national authorities had regulations pertaining to food, primarily with the aim of ensuring fair trade and to prevent consumer deception. Food safety was in the second place. However, these relationships have been changing since the Uruguay negotiations under the GATT (General Agreement on Trade). The results obtained by this agreement are known as Sanitary and Physosanitary SPS and they are related to measures to be taken in order to protect human health from hazards posed by chemical and biological contaminants. According to this agreement, each country can restrict imports of foods for health reasons, which are based on scientific facts and thus to protect their consumers (Ušćebrka, 2011). Also, harmonized international regulations enable the establishment of common standards for international trade of food, and thus creating trust and confidence in the food they find in the market, regardless of the origin of production (Pejanović, 2015).

\section{International Standards}

The need for the introduction of international standards occurred due to extreme growth of international food trade, in order to ensure food quality and safety, but also smooth and fair international trade in food products. Implementation of international standards for food safety can most effectively reduce the risk to consumers' health. The present study gives an overview of the most prevalent. 
Global GAP is one of the most prevalent world standards relating to the primary production of fruit and vegetables. This standard was designed to provide a guarantee to retailers and consumers, and it covers a system of certification, vegetables, fruits, ornamental plants, flowers, fishing, integrated agricultural production, and livestock production. The Government of the Republic of Serbia or more precisely the Agency for Foreign Investments is giving support in the form of non-repayable financial assistance to domestic companies for the introduction and certification of this standard since 2006.

British Retail Consortium (BRC) is a global standard created because of the need for certification bodies to verify the suppliers of food to adhere to uniform rules requirements, in order to avoid duplication or extra work during their checks. The introduction of this standard enables distributors to focus more on market competition.

International Food Standard (IFC) serves as the standardized control of food safety and quality level of producers. This standard should improve food safety and product quality, to improve security and consumer confidence. (Mijatović, Mirčevski, 2012).

In addition to these two standards that are crucial and ensure food safety are the HACCP system and ISO 22000; therefore, a special emphasis will be put on them in this paper.

\section{HACCP and ISO 22000}

HACCP (Hazard Analysis and Critical Points System) was first applied in the Pillsbury Company, which worked for NASA and the US military laboratories. This system was based on the principle of engineering analysis errors, modes and effects dealing with issues of what can potentially go wrong at any stage of the process and it is dealing with the establishing of effective control mechanisms. It was adapted into a system of microbiological food safety in the early stages of the US aerospace research, in order to minimize the likelihood of food poisoning in space. Inspired by the principles and guidelines then used, a new method was developed with a practical and preventive approach that provided a high level of food safety HACCP concept. This concept represents a systematic approach to food safety management, which is based on the approved principles that seek to identify hazards that are likely to occur at some stage in the chain of delivering food, setting control that prevents danger. This system is very logical and it covers all stages of food production from the farm to the consumer, including all sub-processes and distribution. HACCP system was accepted in the seventies and it is internationally recognized by the World International Organization as the most effective means to control food poisoning diseases. HACCP system is the logical technique that follows several steps.

1. Observing of production, step by step, from the beginning to the end, identifying potential risks and assessing the stages at which the danger may occur, as well as ways of setting control in order to prevent the occurrence of danger.

2. Deciding on which of the implemented controls are absolutely critical to food safety.

3. Setting the limit for the security of the operation of conducted critical controls. 
4. Monitoring of controls to make sure they do not exceed safety limits. Monitoring critical limits implies an answer to questions: how, what, how often and who should do it.

5. Identification of corrective measures in case something goes wrong. These measures serve to identify and eliminate the problem.

6. The documentation of requirements and record of all findings on the implementation of HACCP system.

7. The verification that the system works through a regular review which should include persons employed in manufacturing, representatives of inspection at the facility, and of course the HACCP team.

These logical steps build a basis for the use of the seven principles of HACCP and they are internationally recognized. These principles were published by the Codex Alimentarius Commission which was established as a codex by the Food and Agriculture Organization of the United Nations, the World Health Organization, as well as by the National Advisory Committee on Microbiological quality of food in the United States. In addition to general principles and standards, the Codex Alimentarius Commission also brings related documents, i.e. Recommended International Code of Practice (Moltimore, Wallace, 2004).

Starting from January 1, 2006, standards on safe food and above all HACCP control system are obligatory in the market of the Member States of the European Union. Full implementation of the HACCP control system also obliges economy subjects from the third countries as a precondition for placing their products on these markets. (Acin, 2013).

In addition to HACCP standards, it is relevant to analyze the international standards ISO 22000. Specifically, this standard is the first international standard specifying requirements for food safety management system by the organization in the food chain needs to demonstrate their ability to control hazards and product safety for consumption. In order to ensure food safety within the ISO 22000 standard, there were combined the following key elements: management system, interactive communication, previous programs and principles of HACCP. ISO 22000 requirements can be applied to all types of organizations within the food chain, i.e.: food producers, food processors, storage and transport, retail food outlets altogether with interrelated organizations (such as producers of equipment, cleaning, packaging materials, additives, and ingredients). This standard should improve food safety and thereby ensure consumer protection. This should be aimed at strengthening consumer confidence, as well as cost-effectiveness in the supply chain of the food industry. ISO 22000 is consistent with the principles of the HACCP standards and it ensures international compatibility of the application of the HACCP (Mijatović, Mirčevski, 2012).

\section{Consumers and Standards}

Given the fact that food is an unavoidable part of everyday consumption, consumers are increasingly trying to take care of their diet. For this reason, understanding the attitudes, needs, and evaluation of consumers in relation to various issues related to food safety are of 
crucial importance for the development of the system, and standards related to food safety, as well as their implementation. Consumers' behavior in relation to food, in terms of its security, can be adequately predicted if a systematic understanding of how consumers perceive the risks is developed, as well as benefits in connection with various matters of food safety (Savović et. al. 2012). If consumers use food that is unsafe, it may lead to deterioration of health of consumers, leading to increasing economic costs for medical treatment, payment security, absence from work and the like. (Bjelajac et al., 2013). As a result, there has been the development of national standards for the supply of safe food, and many companies and groups involved in food production have developed their own standards or programs to control their suppliers. The development of standards has also been influenced by the growing demand of consumers, increased accountability of sellers, tightening of legal obligations and globalization. In accordance to above mentioned, the Codex standard was developed. The ultimate goal of this standard is to protect consumer's health, prescribe rules for the regulation of agriculture, which means total control of food from seed to final products, as well as ensuring best practices in international food trade (Mijatović, Mirčevski, 2012).

In contemporary culture, food safety is one of the main preoccupations of man. (Bjelajac et al., 2015) On the other hand, the policy of consumer protection has not been provided for in the Treaty on establishing the European Economic Community. Therefore, in the midseventies of the past century, the European Community adopted a resolution on a temporary program of the European Community of Consumer Protection in which they pointed out five basic consumer rights:

1. The right to protection of health and safety,

2. The right to protection of economic interests,

3. The right to compensation, and the remedy,

4. The right to information and education, and

5. The right to the presentation.

The creation of a single internal market (Single European Market) was aimed to remove existing trade barriers between member states and to increase their competitiveness. This single European act (Single European Act) created the legal framework for the subsequent adoption of measures relating to consumer protection. Actually, the functioning of the single market is related to harmonizing consumer protection conditions in the member states. Along with the growth of the Single Market, the number of directives increased as well as other secondary regulations each state brought into their legal system by their free choice (Acin, 2013).

\section{Consumer information}

Consumers often find themselves in a dilemma which food or products to buy. It can be said that their concern became even greater at the end of the previous century when they crossed different varieties to obtain new, more resistant species, and it was helped by the technology 
of genetically modified food (GM). It is essential that consumers have the right to know the facts important for the proper selection of products and to protect themselves from the product labels which mislead them.(Dukić Mijatović, Sudžuka, 2016).

Legal regulations for GM food are very strict in the EU because of the strong consumer mistrust of the European Union towards GM foods. In fact, strong mistrust of European consumers towards GM foods is a consequence of a general distrust of the legal regulations on food safety in the EU. This was certainly contributed by the numerous scandals in this area, among which the most remarkable is "mad cow disease" (Bovine Spongiform Encephalopathy - BSE) in Great Britain. The consumers were very unhappy about the delayed European legislation which did not recognize the risk of BSE on time. Therefore, as a result of this and similar scandals and regulatory failures, European consumers have become very distrustful, even to smallest novelties when it comes to food. This mistrust applies to GM food, as most Europeans do not support GM foods (Vujisić, Mihajlović, 2014).

A consumer estimates quality and health safety of food based on the information provided on the product packaging. It is necessary to mark the foods so that consumers get comprehensive information about the content and composition of the food product. Consumers must have the right to know the important facts relevant for the proper choice and protection on the product labels which mislead them (Košutić et al., 2013). General provisions on labeling food products are contained in the Directive of the European Parliament and Council Directive 2000/13/EC, while Regulation (EC) 1829/2003 on genetically modified animal feed provides a general framework for the regulation of genetically modified food and animal feed in the EU. This framework sets a high level of protection of human life and health, the welfare of the environment and consumers' interests as a global objective, while also ensuring that the internal market functions efficiently. This Regulation was amended by the Regulation (EZ) 1830/2003, which provides traceability and labeling of genetically modified foods placed on the market.

It is necessary that consumers are informed about the safety of the food they consume, but the question is what happens at the moment when the food reaches the consumer's basket. However, relatively little research has been conducted in order to test the consumers' knowledge on food safety and the application of good practices in the preparation of food in households. Based on the modest research, they came to a conclusion that consumers often practice unsafe food handling. This indicates that the consumers need to be pointed out to the application of good practice in the preparation of food in their households (Baltic et al., 2013).

\section{Regulations of the EU and Regulations of the Republic of Serbia}

European legislation on food safety has been developing in several stages. The first stage was focused on building a common market. Its history can be followed from the foundation of the European Economic Community in 1958 to the outbreak of the BSE crisis in the mid-nineties. The first part of this stage was placed on harmonization through vertical 
legislation. ${ }^{4}$ In the second part of the first stage, the focus was shifted to the adoption of the horizontal directive or the directives related to a greater number of products by integrating some common characteristics related to their composition, preparation, trade, etc. (Bunčić, Rudan, 2006).

After the previously mentioned BSE crisis, a more common integrated approach was presented in the European Union, which aims to provide a high level of food safety, animal health, and plant health within the borders of the Union, through the implementation of coherent borders "from farm to fork" and with appropriate monitoring while ensuring the effective functioning of the internal market. The application of this approach involves the development of an adequate legal framework to ensure an effective system of control and evaluation of compliance with the standards of the European Union within the EU but also in third countries in relation to their exports to the EU. Improved legal framework is essential in order to organize international relations with third countries and with international organizations with regard to food safety, as well as to organize relations with the European Food Safety Authority (EFSA) and ensure science-based risk management in this area. The principle of applying integrated approach "from farm to fork", which covers all sectors of the food chain - from production, processing, storage and food processing to retail sales - was presented by the European Commission entitled as the White Paper on Food Safety (Dabović, 2011). This document constitutes the second stage of legislation development in the field of the food safety in the EU. The White Paper on Food Safety was created on January 12, 2000. The action plan on food safety in the Annex to the White Paper contains a list of 84 legal acts. It is believed that in this way the traditional approach to the control of the finished product was abandoned since the system is based on preventive action, i.e. before the product occurs (Glintić, 2012).

It is relevant to point out that before the adoption of the White Paper in May 1997, the Commission published the Green Papers. This document preceded the White Paper and it was published with the aim to start a public debate and consultation on specific issues. The Green Papers underlines its first and most important principle - consumer protection. That is when the control agency in this area was formed - Food and Veterinary Office (FVO) in Dublin, and there was announced the formation of an independent body for food safety, i.e. the future EFSA (Bunčić, Rudan, 2006).

In order to adequately, scientifically and successfully respond to all issues related to food safety, it was decided to found European Food Safety Authority in the framework of the European Union. The main task of this authority is to examine the food safety for humans and

4 Vertical directives are related to specific groups of products with common features and the requirements for the management of their quality. A good example for this type of directive is a discussion about how many foods should contain cocoa in order to be called chocolate and whether other vegetable fats (except the cocoa butter) can be used at all. Directive $73 / 241$, which refers to cocoa and chocolate products intended for human consumption prescribed the content of 35\% cocoa for the entire EU. However, on 3 August 2003 it was changed by a Directive 2003/36 and now some chocolate products can have added some other vegetable fats up to $5 \%$ of the total weight. 
animals, but also to provide scientific opinions on genetically modified foodstuffs covered by the Directive 2001/18/EC (7). With respect to regulations on food and establishment of the European Food Safety Authority, in 2002 and 2003 were adopted two regulations. The first Regulation 178/2002 of the European Parliament and the Council established the general principles and requirements of the law on food, and the second, Commission Regulation $1304 / 2003$ on the procedure applied by the European Food Safety Authority related to the requirements for issuing scientific opinions related to it (Vilus, 2009).

The Regulation 178/2002 (Regulation (EC) No. 178/2002) comprises 65 members and it directly applies to all Member States. It is divided into the following chapters: the scope and general definitions (Art. 1-3), the general rules on foodstuffs (Art. 4-21), the European Food Safety Authority (Art. 22-49), the rapid alert system, crisis management and emergency cases (Arts. 50-60), and procedures and final provisions (Arts. 58-65). The regulation 1304/2003 (Commission Regulation (EC) No. 1304/2003) shall specify the procedure in the case when the Authority is required a scientific opinion on food safety, which are normally required by the Article 29 of the Regulation 178/2002. The Regulation 1304/2003 provides the existence of a register which records each request in terms of food testing.

Legislation in this area has developed over time in accordance with scientific, social, political and economic needs. Thus, in the period from 2000 to 2004 the European Union committed significant changes and contractions of numerous regulations in the field of veterinary medicine, as part of a special Law on Food Safety of the EU adopted in 2002, which adopted regulations relating to food safety, i.e. Regulation 852/2004 on the hygiene of foodstuffs; Regulation 853/2004 which defines necessary rules and regulations in the field of food hygiene for food of animal origin; Regulation 882/2004 on official controls to be carried out in order to comply with the Law on Animal Feed; Decision 2004/478EC - the adoption of a comprehensive plan in case of crisis management caused by food/animal feed. This longstanding and systematic approach of the EU countries is aimed at facilitating the mutual and international trade by ensuring the quality of partners involved in the sale of food, but it also reduces the cost related to traffic and control.

Due to the fact that Serbia is strategically destined to join the European Union, it is necessary to harmonize its legislation with the EU legal acquisitions. Accordingly, from January 1, 2009, application of HACCP system became a legal obligation for food manufacturers on the territory of the Republic of Serbia.

The reform of the food safety in Serbia started in 2005 with the adoption of the Veterinary Act (Official Gazette No. 91/2005, 30/2010), while legislation in the field of agriculture was most fertile from 2009 to 2010. During this period were adopted more than 30 laws in this area. Among other, there were adopted: Law on Agriculture and Rural Development (Official Gazette of RS 41/09), the Law on Food Safety (Official Gazette of RS, No. 41/2009), the Law on Animal Husbandry (Official Gazette of RS, No 41/2009), the Law on Genetically Modified Organisms (Official Gazette of RS, No 41/2009), the Law on Plant Health (Official Gazette of RS, No 41/2009), etc.

The Law on Food Safety started a comprehensive reform in the field of food safety by EP 2017 (64) 1 (191-204) 
harmonizing standards and regulations with accepted international and European regulations and standards. The main objective of this law is to primarily provide a high level of protection of human life and health and protection of consumers' interests, including the principle of good faith in trade of food, but taking into account (when possible) protection of animal health and welfare, as well as health of plants and environmental protection (Art. 1-3); as the principles of this Act were defined: the principle of risk analysis, precautionary principle, the principle of consumer protection and the principle of transparency. The principle of traceability was adopted, i.e. monitoring of the origin of food at all stages of production, transport, and processing of food and animal feed. This raises the requirements for the registration of all participants in the chain of food production and circulation. The law stipulates that the food safety in the territory of the Republic of Serbia, in the framework of their powers, are provided by entities which are registered in the Central Register of objects, then the Ministry of Agriculture, Forestry and Water Management, Ministry of Health, and the referenced (accredited) laboratories. The law defines the duties of the state administration in the field of food safety. Article 25 of the Act imposes a ban on the marketing of unsafe food, precisely stating which food. Also, regarding the definition of food hygiene, the law provides that food business operators are required to at all stages of production, processing, and distribution of food under their control, to meet the prescribed requirements relating to food hygiene. This means that all persons whose jobs are in the production and distribution of food and come into contact with food must have basic knowledge of food hygiene, but also about personal hygiene and must wear working clothes and shoes. The law also contains rules on genetically modified food and genetically modified animal feed. One of the relevant principles of law is the principle of protecting the interests of consumers, which means that all food business operators are obliged to inform consumers about the composition, properties, and purpose of products.

The adoption of the Law on Food Safety and the Law on Veterinary Practice led to the adoption of a number of ordinances such as: the Ordinance on General and Specific Food Hygiene Requirements at any Stage of Production, Processing and Transport, Regulations on Food Hygiene Requirements, the Ordinance on the Requirements for Labeling and Advertising of Animal Feed, and so on. Based on the foregoing, it can be said that the Republic of Serbia legislation that regulates the field of food safety and consumer protection is largely in line with international standards, as well as with the relevant EU regulations.

\section{Conclusion}

Normative analysis leads to the conclusion that only if the national legal regulations relating to food are in line with international regulations, it is possible to establish common standards for international trade of food, which in turn leads to the development of safety and confidence in the food on the market regardless of its origin. By analyzing and studying the legislation related to food safety from the aspect of modern society, it can be concluded that food safety is one of the main preoccupations of the safety culture of modern man and it is receiving substantial attention. This is indicated by the existence of international standards and regulations of the European Union. EU legislation related to food safety is mainly governed by the regulations 
and directives that are applied in all Member States. In fact, food safety is the key issue in food legislation in the European Union, and the crisis in the nineties emphasized food security as one of the most important policy priorities of food in the EU, which led to the reconstruction of the European Union legislation on food.

Based on these findings, it can be concluded that food safety in the European Union is of great importance not only to protect the health of consumers but also because of economic importance. An integrated approach to EU food safety aims to facilitate and ensure a high level of food safety, animal health, animal welfare and plant health within the Union, using coherent measures "from farm to fork", thus covering all sectors of the food chain. The legal framework in this area is presented in the White Paper on Food Safety and directives, ordinances and regulations.

In the Republic of Serbia, the adoption of the Law on Food Safety made a big step forward. The Law itself has initiated the adoption of a large number of by-laws. However, it is relevant to point out that it is very important, in the best possible way, to prepare production, packing and sale of goods with adequate supporting documentation evidencing of compliance with all standards and norms of the European Union, without which business deals would not be possible.

\section{Literature}

1. Acin, I. Đ. (2013): Zdravstveno bezbednosni standardi prehrambenih proizvoda kao oblik zaštite potrošača u Evropskoj uniji, Poslovna ekonomija, vol. 7, no. 1, pp. 259-277, Fakultet za uslužni biznis, Sremska Kamenica, Republika Srbija

2. Baltić, M., Đurić, J., Mandić, S., Pećanac, B., Ločina, J. (2013): Potrošači i bezbednost hrane, Glasnik hemičara, tehnologa i ekologa Republike Srpske, vanredno izdanje, pp. 11-16, Tehnološki fakultet, Banja Luka, Bosna i Hercegovina

3. Bjelajac Z., Pocuca M., Dukic-Mijatovic M.(2013): Uranium and Dioxin Consequences of Bombing of Yugoslavia in 1999 and Its Impact on the Ecosystem and Human Health, Journal of Environmental Protection and Ecology, vol.14, no. 2, pp. 480-492, Balkan Environmental Association, Thessaloniki, Greece

4. Bjelajac Z., Dukic-Mijatovic, M., Kozar, V. (2015):Review of the Uncontrolled Use of Certain Chemicals and Their Adverse Effect on Human Health and Safe Environment, Oxidation Communications, vol. 38, no2, pp. 722-733, SciBulCom, Sofia, Bulgaria

5. Bunčić, O., Rudan, A. (2006): Pravni okviri i institucije EU značajni za bezbednost hrane, Tehnologija mesa, vol. 47, no. 1-2, pp. 1-7, Institut za higijenu i tehnologiju mesa, Beograd, Republika Srbija

6. /Codex Alimentarius Commissions Recommended International Code of Practice: General Principles of Foode Hygiene CAC/RCP 1-1969, Rev. 4, 2003

7. Commission Regulation (EC) No. 1304/2003 of 11th July on the procedures applied by the European Food Safety Authority to request for scientific opinions referred to it OJ, L $18524.7,2003$ 
8. Dabović, D. (2011): Propisi Evropske unije u oblasti bezbednosti hrane, Evropskozakonodavstvo. vol. 10, no. 37/38, pp. 177-187, Institut za međunarodnu politiku i privredu, Beograd, RepublikaSrbija

9. Dukić-Mijatović, M., Gongeta, S. (2015): Nova Direktiva o pravima potrošača u Evropskoj uniji, Evropsko zakonodavstvo, vol. 14, no. 51, pp. 148-160, Institut za međunarodn upolitiku i privredu, Beograd, Republika Srbija

10. Dukić-Mijatović, M., Sudžuka E. (2016):Usklađenost prava zaštite potrošača Republike Srbije i Bosne i Hercegovine sa pravom Evropske unije, Evropsko zakonodavstvo, vol. 15, no. 56-57, pp. 142.-159, Institut za međunarodnu politiku i privredu, Beograd, Republika Srbija

11. Dukic-Mijatovic M., Bjelajac Z., Kozar, V. (2016):Flood Risk Management Analysis for Reducing Harmful Effects on Human Health, Environment, Cultural Heritage and Economic Activity in the Republic of Serbia, Oxidation Communications, vol. 39, no 1, pp. 399-410, SciBulCom, Sofia, Bulgaria

12. European Parliament and Council Directive 2000/13/EC on the approximation of the laws of the Member States relating to the labeling, presentation and advertising of foodstuffs, OJL 109, 6.5.2000

13. Glintić, M. (2012): Bezbednost hrane, Usklađivanje prava Republike Srbije sa pravnim tekovinama EU, Beograd, Republika Srbija, pp. 75-86

14. Košutić, M., Filipović, J., Plavšić, D., Živković, J., Nježić, Z., Filipčev, B. (2013): Consumers Attitudes towards Food Safty Messages, Journal on Processing and Energy in Agriculture, vol. 17, no. 4, pp. 184-186, Nacionalno društvo za procesnu tehniku i energetiku u poljoprivredi, Novi Sad, Republika Srbija

15. Law, G. F. (2002): Regulation (EC) No. 178/2002 of the European Parliament and of the Council of 28 January 2002, laying down the general principles and requirements of food law, establishing the European Food Safety Authority, and laying down procedures in matters of food safety. OJ L, 31(1.2)

16. Mijatović, R., Mirčevski, M. (2012): Sistem menadžmenta bezbednosti hrane, Vojno delo, vol. 64, no. 1, pp. 337-355, Ministarstvo odbrane Srbije - Vojnoizdavački zavod, Beograd, Republika Srbija

17. Moltimore, S., Wallace, C. (2004): HACCAP: u proizvodnjihrane i pića, Novi Sad, Mobes quality, RepublikaSrbija

18. Pejanović, R. (2015): Neodrživostdosadašnjegkonceptarazvoja i problem bezbednosti hrane, LetopisnaučnihradovaPoljoprivrednogfakulteta, vol. 39, no. 1, pp. 141-152, Poljoprivrednifakultet, Novi Sad, RepublikaSrbija

19. Regulation (EC) 1829/2003 on genetically modified food and feed provides general framework for regulating genetically modified, OJ L 268, 18.10.2003.

20. Regulation (EC) 1830/2003 which ensures traceability and labeling of GMOs placed on the marker, available on: http://eur-lex.europa.eu/legal-content/en/TXT/PDF/?uri=CEL EX:02003R1830-20081211 
21. Savović, I., KokićArsić, A., KanjevacMilovanović, K., Đorđević, A. (2012): Kvalitet i bezbednosthraneizuglakorisnika, Zbornikradovasanacionalnekonferencije o kvalitetu i o kvalitetuživota, Kragujevac, RepublikaSrbija, pp. 105-112

22. Sič, M. (2013): Zaštita životne sredine: zaštita zdravlja i bezbedna hrana-EU i Srbija, Zbornik radova Pravnog fakulteta u Novom Sadu, no. 1, pp. 209-227, Pravni fakultet, Novi Sad, Republika Srbija

23. The Green Papers - The European Food Policy, available on: http://europa.eu/rapid/ press-release_IP-97-370_en.htm

24. Ušćebrka, G. (2011): Pregled propisa koji se odnose na kvalitet hrane, Tehnika, vol. 66, no. 1, pp. 161-167, Savez inženjera i tehničara Srbije, Beograd, Republika Srbija

25. Vilus, J. (2009): Propisi o osnivanju Evropske uprave za bezbednost hrane, Vodič kroz pravo Evropske unije, Beograd, Republika Srbija, pp. 408-411

26. Vujisić, D., Mihajlović, B. (2014): Genetski modifikovana hrana-pravo potrošača na izbor i obaveštenost, Pravo i privreda, vol. 52, no. 7-9, pp. 283-296, Udruženje pravnika u privredi Srbije, Beograd, Republika Srbija

27. Zakon o bezbednosti hrane, Službeni glasnik Republike Srbije, no. 41/2009

28. White paper on Food Safety, Commission of the European Communities 719/1999 http:// ec.europa.eu/dgs/health_food-safety/library/pub/pub06_en.pdf) 


\title{
BEZBEDNOST HRANE KAO JEDNA OD OSNOVNIH PREOKUPACIJA BEZBEDNOSNE KULTURE SAVREMENOG ČOVEKA
}

\author{
Željko Bjelajac ${ }^{5}$, Marijana Dukić-Mijatović ${ }^{6}$,Joko Dragojlovič ${ }^{7}$
}

\section{Rezime}

Industrijalizacija, proizvodnja u poljoprivredi i upotreba hormona, aditiva, pesticida i sl., uticali su na to da se poveća nezadovoljstvo potrošača, što je dovelo do gubitka njihovog poverenja u institucije koje su zadužene za kontrolu bezbednosti hrane. Kao rezultat navedenog došlo je do izmena $i$ donošenja strožih zakonskih regulativa koje su pratile koncept „od njive do trpeze” kako na nivou Evropske unije, tako i u Republici Srbiji. Stavlja se akcenat na potošača i njegovo pravo da raspolaže činjenicama koje su od značaja za pravilan izbor proizvoda (hrane). Shodno tome, razvijaju se međunarodni standardi kojima se obezbeđuje kvalitet i bezbednost hrane. Stoga je cilj rada da se kroz metodološko-teorijski okvir analizira bezbednost hrane i to sa aspekta savremenog čoveka. Metodom analize će biti razloženi pojmovi koji se odnose na bezbednost hrane, dok će normativni metod poslužiti za prikaz legislativa koje regulišu proučavanu materiju bezbednosti hrane i zaštite potrošača na nivou Evropske unije i Republike Srbije, a kroz komparativni metod biće poređeni i sumirani dobijeni rezultati.

Ključne reči: bezbednost hrane, zaštita potrošača, međunarodni standardi, EU, harmonizacija, Republika Srbija.

5 Redovni profesor, dr Željko Bjelajac, Univerzitet Privredna akademija, Pravni fakultet za privredu i pravosuđe u Novom Sadu, Ulica Geri Karolja br. 1, 21000 Novi Sad, Republika Srbija, Telefon: +381 644628 967, E-mail: zdjbjelajac@gmail.com

6 Redovni profesor, dr Marijana Dukić-Mijatović, Univerzitet Privredna akademija, Pravni fakultet za privredu i pravosuđe u Novom Sadu, Ulica Geri Karolja br. 1 i Univerzitet u Novom Sadu, Ekonomski fakultet u Subotici, Segedinski put br.9-11, 24000 Subotica, Republika Srbija, Telefon: +381 63542 093, E-mail: marijana.dukic.mijatovic@gmail.com

7 Docent, dr Joko Dragojlović, docent, Univerzitet Privredna akademija, Pravni fakultet za privredu i pravosuđe u Novom Sadu, Ulica Geri Karolja br. 1, 21000 Novi Sad, Republika Srbija, Telefon: +381649429936, E-mail: jdragojlovic@pravni-fakultet.info 
ECONOMICS OF

AGRICULTURE

\section{CONTENT}

1. Željko Anđelković, Aleksandra Dragin, Sanja Božić, Kristina Košić

EMOTIONAL EXHAUSTION AND JOB SATISFACTION OF TOUR GUIDES IN RURAL AREAS . . . . . . . . . . . . . . 11

2. Sanja Đukić, Danica Glavaš-Trbić, Nikola Banjac

MANAGEMENT PROBLEMS OF RURAL DEVELOPMENT IN FRUŠKA GORA . . . . . . . . . . . . . . . . . . . . 27

3. Ivana Ilić, Bojan Krstić, Sonja Jovanović

ENVIRONMENTAL PERFORMANCES OF AGRICULTURE IN THE EUROPEAN UNION COUNTRIES . . . . . . . . . . . . . 41

4. Nataša Kljajić, Jonel Subić, Zorica Sredojević

PROFITABILITY OF RASPBERRY PRODUCTION

ON HOLDINGS IN THE TERRITORY OF ARILJE. . . . . . . . . . . 57

5. Aleksandar Maksimović, Zoran Grgić, Ferhat Ćejvanović

MULTI-ATTRIBUTE ANALYSIS OF ORCHARD ACCORDING

TO THE INTEGRATED PRODUCTION CONCEPT . . . . . . . . . . 69

6. Ozrislava Milinković, Branislav Jakić, Slobodan Vuksanović,

Dragana Macura, Milica Šelmić

MULTI- CRITERIA DECISION BASED APPROACH

TO SELECTING THE TYPE OF INDUSTRIAL HALLS

USED IN FOOD INDUSTRY $\ldots \ldots \ldots \ldots$. . . . . . . . . . 81

7. Gordana Nikić, Ljubiša Stamatović, Azra Sućeska

EMOTIONAL COMPETENCIES AND PERSONALITY

TRAITS OF MANAGERS IN MODERN AGROBUSINESS. . . . . . . .97

8. Vladimir Obradović, Nemanja Karapavlović

FINANCIAL REPORTING OF COMPREHENSIVE INCOME

IN THE FOOD AND BEVERAGE SECTOR

IN THE REPUBLIC OF SERBIA . . . . . . . . . . . . . . 113 
9. Aleksandar Ostojić, Nebojša Savić, Željko Vaško

CONSUMER ATTITUDES

ON BUYING FISH IN BANJA LUKA . . . . . . . . . . . . . . . 129

10. Radivoj Prodanović, Boris Kuzman, David Jovović, Lazar Ozegović

MARKET AND TRADE OF ORGANIC FRUITS IN SERBIA $\ldots . . .141$

11. Predrag Vukadinović, Aleksandar Damnjanović, Ljiljana Dimitrijević

ANALYSIS OF THE SALES AND INCOMES BETWEEN

DIFFERENT CATEGORIES OF AGRICULTURAL PRODUCTS . . . 157

12. Jugoslav Aničić, Svetlana Vukotić, Goran Maksimović

THE POSSIBILITIES AND LIMITATIONS

OF ENTREPRENEURSHIP DEVELOPMENT

IN AGRICULTURE IN SERBIA . . . . . . . . . . . . . . 171

13. Željko Bjelajac, Marijana Dukić - Mijatović, Joko Dragojlović

FOOD SAFETY AS ONE OF THE MAIN SAFETY $P$

REOCCUPATIONS OF A MODERN MAN . . . . . . . . . . . . . 191

14. Milan Bradić, Ljiljana Kosar, Lukrecija Djeri, Svetlana Vukosav, Vuk Garača

ECO-LABELLING OF ACCOMMODATION FACILITIES

AND ITS PERCEPTION BY RURAL TOURISTS:

CASE STUDY OF VOJVODINA . . . . . . . . . . . . . . 205

15. Vaso Jegdić, Iva Škrbić, Srđan Milošević

MODELS OF ENTREPRENURSHIP DEVELOPMENT

IN RURAL TOURISM DESTINATIONS IN VOJVODINA . . . . . . . 221

16. Duško Kuzović

MUSEUM OF VERNACULAR ARCHITECTURE OF WESTERN SERBIA

- Representative curtilages of the area surrounding middle

course of the river Drina and Podgorina . . . . . . . . . . . 239

17. Branko Mihailović, Zoran Simonović, Nikola Ćurčić

AGRICULTURAL RESOURCES AND DEVELOPMENT

PRIORITIES OF THE MUNICIPALITY OF STARA PAZOVA. . . . . 259

18. Radmilo Nikolić, Aleksandra Fedajev, Vidoje Stefanović, Silvana Ilić

THE AGRICULTURE SECTOR IN WESTERN BALKANS

- SOME CHARACTERISTICS OF DEVELOPMENT. . . . . . . . . . 275

19. Vladimir Njegomir, Rajko Tepavac, Nenad Ivanišević

ALTERNATIVE SOURCES OF FINANCING

ENTREPRENEURIAL UNDERTAKINGS IN AGRICULTURE . . . 295

Economics of Agriculture, Year 64, No. 1 (1-404) 2017, Belgrade 
20. Daniela Nuševa, Kristina Mijić, Dejan Jakšić

THE PERFORMANCES OF COFFEE PROCESSORS

AND COFFEE MARKET IN THE REPUBLIC OF SERBIA . . . . . . 307

21. Svetlana Roljević Nikolić, Predrag Vuković, Biljana Grujić

MEASURES TO SUPPORT THE DEVELOPMENT OF ORGANIC

FARMING IN THE EU AND SERBIA . . . . . . . . . . . . 323

22. ŽeljkoVojinović, Vera Zelenović, DragoCvijanović

PROGRAM OF STATE SUPPORT

TO AGRICULTURAL CREDITING. . . . . . . . . . . . . . . . 339

23. Nikola Vuksanović, Dragan Tešanović, Bojana Kalenjuk,

Milijanko Portić, Marija Knežević

SOCIO-DEMOGRAPHIC CHARACTERISTICS

AS DETERMINANTS OF DIFFERENCES

IN PERCEPTION OF LOCAL GASTRONOMY . . . . . . . . . . . . 359 